\title{
Relações semânticas entre texto e música em Três Canções sobre Poemas de Fernando Pessoa
}

\author{
Semantic Relationships between text and music in Three Songs about \\ Poems by Fernando Pessoa
}

\author{
Flávio Santos Pereira \\ Universidade de Brasília
}

\begin{abstract}
Resumo: Neste artigo procura-se explicitar os processos composicionais utilizados para criar relações semânticas entre texto e música. Obra do próprio autor, Três Canções sobre Poemas de Fernando Pessoa, para canto e piano, é tomada como objeto de análise. Em primeiro lugar, são abordados criticamente os pressupostos teóricos que nortearam o processo criativo, apoiado no pensamento filosófico de Susanne K. Langer e no pensamento semiótico de Raymond Monelle. Em seguida, são explicitados e ilustrados, com exemplos de Três Canções sobre Poemas de Fernando Pessoa, os procedimentos técnico-composicionais desenvolvidos e aplicados na materialização das relações semânticas, na complexa interação entre texto e música.
\end{abstract}

Palavras-chave: Semântica Musical; Análise Musical; Processo Composicional.

Abstract: This article seeks to explain the compositional processes used to create semantic relations between text and music. The author's own work, Three Songs about Poems by Fernando Pessoa, for singing and piano, is taken as the object of analysis. Firstly, the theoretical assumptions that guided the creative process, based on Susanne K. Langer's philosophical thinking and Raymond Monelle's semiotic thinking, are critically addressed. Then, with examples from Three Songs about Poems by Fernando Pessoa, the technical-compositional procedures developed and applied in the materialization of semantic relations, in the rich interaction between text and music, are explained and illustrated.

Keywords: Musical Semantics; Musical Analysis; Compositional Process. 


\title{
1. Introdução
}

\begin{abstract}
"Muitos anos depois, diante do pelotão de fuzilamento, o coronel Aureliano Buendía havia de recordar aquela tarde remota em que seu pai o levou para conhecer o gelo." Não tinha a menor ideia do significado ou da origem dessa frase, nem para onde iria me conduzir.
\end{abstract}

(García Márquez, Gabriel. Eu não vim fazer um discurso. Rio de Janeiro: Record, 2011, p. 112-113)

Escrever sobre a própria experiência criativa nos defronta com diversos dilemas. É legítimo ao compositor elucidar os seus processos composicionais, tornar explícitas as suas preocupações estéticas? A história nos mostra que a obra está para além do seu criador, seja no plano espacial, temporal ou simbólico. $\mathrm{O}$ potencial de sentido da obra está muito mais na recepção do grupo social e se renova nos significados socialmente atribuídos do que no conjunto de intenções do compositor, das suas ambições pessoais. Porém, se afastamos a visão romantizada do criador, se reconhecemos como igualmente legítimas as várias instâncias que irão compor a visão social da obra, há um espaço ético para a contribuição do próprio compositor, consciente este da impossibilidade de qualquer estudo que se pretenda exaustivo, das percepções equivocadas que podem resultar de uma abordagem marcada por uma perspectiva subjetiva e evasiva. Deve-se fazer o esforço de trazer questões que se mostrem relevantes, embora a proximidade com o processo criativo muitas vezes turve a visão analítica. Para o próprio compositor há, sem dúvida, alguns benefícios de reconhecida importância no exercício de lançar um olhar sistematizador sobre a própria produção. No processo criativo inúmeros passos são tomados intuitivamente, por uma intuição orientada, tomando a expressão de empréstimo a John Rink (2002). ${ }^{1} \mathrm{O}$ esforço em compreender o processo composicional, de

\footnotetext{
${ }^{1}$ Propus o termo 'intuição informada', no qual se reconhece a importância da intuição no processo de interpretação, mas, também, o conhecimento e a experiência considerável que está por detrás dela. Em outras palavras, a intuição não necessita surgir do nada e não precisa ser unicamente caprichosa. (Tradução nossa)

I also proposed the term 'informed intuition', which recognizes the importance of intuition in the interpretative process but also that considerable knowledge and experience generally lie behind it - in other words, that intuition need not come out of the blue, and need not be merely capricious.
} 
sistematizar as forças que o organizam, de conceber e fundamentar uma teoria, é essencial para se dar um passo adiante no percurso técnico e estético característico de qualquer trajetória criativa. Abre horizontes para a permanente inquietação criadora. Confessamos, é em benefício próprio que empreendemos o trabalho de lançar luz em alguns aspectos de Três Canções sobre Poemas de Fernando Pessoa. ${ }^{2}$ Este artigo, a explicitar a orientação estética, pretende elucidar algumas soluções técnico-composicionais utilizadas em Três Canções sobre Poemas de Fernando Pessoa para criar, evidenciar e conciliar elementos semânticos musicais e textuais. Porém, alertamos, fazemo-lo ciente de que não deve ser dada ao compositor uma posição privilegiada na interpretação da própria obra. Há e sempre haverá analistas contextualmente mais competentes, suficientemente distanciados, para inserir a obra numa perspectiva mais justa dos pontos de vista técnico e social. Se for o caso, assinalamos, da obra despertar algum interesse que ultrapasse o do próprio criador.

\section{Questões e problemática da Significação Musical}

As questões e problemática da significação musical, suas implicações no plano técnico-composicional, determinam a perspectiva analítica adotada neste artigo. A linguagem musical em Três Canções sobre Poemas de Fernando Pessoa, obra objeto do trabalho analítico, é densamente cromática, mas não recorre a práticas deterministas, a técnicas de pré-ordenação. A saturação cromática é princípio fundamental a determinar a construção melódica e harmônica, mas guiada por práticas que asseguram a liberdade de escolha no transcurso do próprio processo composicional e o pleno exercício da criatividade em todos os níveis da composição. Há, claro, princípios diretivos, norteadores, atrelados à estética buscada, que serão clarificados ao longo do trabalho.

Colocar a significação musical no centro das preocupações, tomá-la como principal determinante das decisões composicionais, implica numa permanente reflexão quanto a sua natureza. As perspectivas são quase tantas quantos são os compositores, musicólogos, teóricos, psicólogos, antropólogos e filósofos que

\footnotetext{
2 Três Canções sobre Poemas de Fernando Pessoa foi estreada por Luciana Kiefer e Fernando Rauber, piano, em 2 de novembro de 2008, no auditório do Instituto Goethe, em Porto Alegre-RS, na programação do V Festival Contemporâneo. Foi apresentada na XVIII Bienal de Música Brasileira Contemporânea por Maíra Lautert e a pianista Priscila Bomfim, na sala Cecília Meireles, em 25 de outubro de 2009.
} 
MUSICA THEORICA Revista da Associação Brasileira de Teoria e Análise Musical 2019, v. 4, n. 2, p. 134-158 - Journal of the Brazilian Society for Music

abordaram a questão. Para nós interessa, especialmente, a perspectiva do compositor, que, parece-nos, tem sido aquela em menor evidência e a menos valorada. Não cabe ao compositor encontrar ou não significado na experiência musical, seja no processo criativo seja na própria obra já consolidada. Ao compositor, é o nosso pensamento, conforme a sua vontade, cabe dotar ou não a música - linguagem na qual se expressa ou ao menos se exercita - de significado. Privilegiar a perspectiva do compositor, insistimos, não significa desprezar ou ignorar as demais perspectivas, mas abordar e relevá-las de acordo com uma ótica específica e, reconhecemos, parcial, mas indiscutivelmente necessária.

No seu capítulo introdutório, Monelle (1992), no seu breve comentário acerca de Hanslick, conclui: "[...] ele tem uma importante recomendação para os semiólogos da música: investigar a maneira de significação, não a matéria significada" (p. 11). Entretanto, ao final deste mesmo capítulo, escreverá Monelle: "A ideia da semântica musical tem-se tornado respeitável" (p. 31). ${ }^{4} \mathrm{O}$ compositor, no seu processo criativo, tem que se ocupar igual e concomitantemente tanto da maneira - dos procedimentos, da técnica, do estilo - quanto da matéria significada - a semântica musical. O compositor cria símbolos. E o faz a criar signos e a provocar a instauração de relações entre os signos criados e conteúdos emocionais e intelectuais.

Langer (2004) estabelece em Filosofia em Nova Chave as bases e diretrizes para a compreensão da condição de linguagem da música, para a compreensão da música como fenômeno simbólico. O que distingue uma obra de arte de um 'mero' artefato (p. 205) é, assevera Langer, a "forma significativa", qualidade comum a todas as obras de arte, e fundamento de uma nova filosofia da arte. Langer recusa a teoria psicanalítica da estética, critica a impossibilidade de a teoria estabelecer sequer "o mais rude critério de excelência artística" (p. 208). Na sua análise, Langer descarta a "resposta emocional" (p. 212) ou "a crença no poder afetivo da música" (p. 213), onde se assentam as concepções da influência da música no comportamento. Não reconhece a validade da doutrina da autoexpressão - que "chegou aos nossos dias, sendo amplamente aceita por

\footnotetext{
${ }^{3}[\ldots]$ he has important advice for music semiologists: study the manner of signification, not the matter signified.

${ }^{4}$ The idea of musical semantics has become respectable.
} 
músicos e filósofos igualmente" - onde se abriga "a crença de que a música é uma catarse emocional" (p. 215). Para Langer:

[...] a crença de que a música é em essência uma forma de autoexpressão defronta-se logo com um paradoxo; filosoficamente, estaciona quase no seu próprio começo. Pois a história da música tem sido uma história de formas cada vez mais integradas, disciplinadas e articuladas, muito parecida com a história da linguagem, que se faz importante apenas quando se desapega de sua antiga fonte nos gritos expressivos, e se torna denotativa e conotativa mais do que emocional (p. 216).

Langer sentencia: “A pura autoexpressão não requer forma artística." E mais: "As leis da catarse emocional são leis naturais, não artísticas." (p. 216) Admite que "podemos usar música para descarregar nossas experiências subjetivas e restaurar nosso equilíbrio pessoal, mas esta não é sua função primária" (p. 217). Afirma: "Se a música tem qualquer significação, é semântica, não sintomática. [...] se tem um conteúdo emocional, ela o 'tem' no mesmo sentido que a linguagem 'tem' seu conteúdo conceitual - simbolicamente. [...] A música não é a causa ou a cura de sentimentos, mas sua expressão lógica" (p. 217-218).

Langer recorre "ao desenvolvimento da música 'dramática' em um sentido mais subjetivo - música que é projetada e acolhida como linguagem de sentimentos." Afirma, com o pensamento voltado para o compositor: "[...] se a música é de fato uma linguagem da emoção, expressa em primeiro lugar o conhecimento do sentir humano do compositor" (p. 220).

Ao citar Wagner, Langer comenta:

[...] a música não é autoexpressão, mas formulação e representação de emoções, disposições, tensões mentais e resoluções - um 'quadro lógico' de vida senciente e responsiva, uma fonte de compreensão, não uma súplica de simpatia. Os sentimentos revelados na música são essencialmente não 'a paixão, o amor ou o anelo de um dado indivíduo', convidando-nos a nos colocarmos no lugar desse indivíduo, mas são apresentados diretamente ao nosso entendimento, a fim de que possamos apreender, conceber, compreender esses sentimentos, sem pretender tê-los ou imputá-los a qualquer outra pessoa. Assim como as palavras podem descrever eventos que não presenciamos, lugares e coisas que não vimos, a música pode apresentar emoções e estados de espírito que não sentimos, paixões que antes não conhecíamos. Seu tema é o mesmo que o da 'autoexpressão', e seus símbolos podem até ser emprestados, de vez em quando, do reino dos sintomas expressivos; todavia os elementos sugestivos tomados de 
MUSICA THEORICA Revista da Associação Brasileira de Teoria e Análise Musical 2019, v. 4, n. 2, p. 134-158 - Journal of the Brazilian Society for Music

empréstimo são formalizados, e o tema 'distanciado' em uma perspectiva artística (p. 221).

No pensamento de Langer o compositor "não apenas indica, mas articula complexos sutis de sentimento, que a linguagem não pode sequer denominar e muito menos descrever; ele conhece as formas de emoção e sabe manejá-las, 'compô-las'”' (p. 222).

"O conteúdo", reflete Langer, "foi simbolizado para nós, e o que ele solicita não é resposta emocional, mas introvisão (insight). [...] se o conteúdo for a vida de sentimento, impulso, paixão, então os símbolos que o revelam não serão os sons ou as ações que normalmente expressariam esta vida; não são os signos associados, mas as formas simbólicas é que devem transmiti-lo ao nosso entendimento" (p. 222-223).

Acerca da pertinência do uso simbólico das formas musicais, constata Langer:

Assim o primeiro requisito para um relacionamento conotativo entre música e experiência subjetiva, uma certa similaridade de forma lógica, é por certo satisfeito. Além disso, não resta dúvida de que as formas musicais possuem determinadas propriedades que as recomendam para o uso simbólico: compõem-se de muitos itens separáveis, facilmente produzidos e combinados em grande variedade de modos; em si, não representam nenhum papel prático importante capaz de lhes eclipsar a função semântica; são prontamente distinguidas, lembradas e repetidas; e finalmente, têm notável tendência para modificar mutuamente os caracteres em combinação, como fazem as palavras, todas servindo a cada uma como contexto (p. 226).

Quanto à capacidade simbólica da música, Langer assevera: “[...] o que a música pode efetivamente refletir é apenas a morfologia do sentimento." Acerca da importância e do caráter essencial, continua Langer: "Se ela [a música] revela às nossas mentes o racional dos sentimentos, o ritmo e o padrão da ascensão, da queda e do entrelaçamento destes, então ela é uma força em nossa vida mental, nossa consciência e nosso entendimento, e não apenas em nossa experiência afetiva" (p. 236).

À exceção da "conotação adjudicada", a música, escreve Langer, "ostenta todas as marcas de um verdadeiro simbolismo". "Ela é uma forma capaz de conotação, e os significados aos quais é acessível são articulações de experiências emotivas, vitais e sencientes" (p. 237). A impossibilidade da adjudicação reside na natureza da música ser um símbolo não-consumado, "embora seja claramente uma forma simbólica": 
A articulação é sua vida, mas não a asserção; a expressividade, não a expressão. A função real do significado, que requer conteúdos permanentes, não é preenchida; pois a adjudicação de um em vez de outro significado possível para cada forma nunca é feita de maneira explícita. A música, portanto, é 'Forma Significante', no sentido peculiar de 'significante' que Bell e Fry afirmam poder apreender, ou sentir, mas não definir; tal significação é implícita, mas não convencionalmente fixada (p. 238).

Permitimo-nos a ressalva de que a música pode ser, plenamente, forma significante, para a qual é possível fazer valer a força da convenção, mas apenas no interior de uma mesma obra ou contexto específico, mas convenção cujo alcance é circunscrito, próprio de uma obra ou contexto específico, não generalizável, que é, com Langer, como entendemos o sentido da significação implícita, "mas não convencionalmente fixada".

Acerca do poder real da música, da natureza pessoal da imaginação que lhe responde, da atribuição de significado, escreve Langer:

O poder real da música reside no fato de que lhe é dado, de um modo impossível para a linguagem, ser "fiel" à vida do sentir; pois suas formas significativas têm aquela ambivalência de conteúdo que as palavras não podem ter. [...] A música é reveladora, lá onde as palavras são obscurecedoras, porque lhe é permitido ter não apenas um conteúdo, mas um jogo transiente de conteúdos. Ela pode articular sentimentos sem ficar casada com eles. [...] A atribuição de significados é um jogo cambiante, caleidoscópico, provavelmente abaixo do limiar da consciência, certamente fora do âmbito do pensar discursivo. A imaginação que responde à música é pessoal, associativa e lógica, matizada de afeto, de ritmo corporal, de sonho, mas preocupada com um tesouro de formulações para seu tesouro de conhecimento sem palavras, seu conhecimento todo da experiência emocional e orgânica, de impulso vital, equilíbrio, conflito, os modos de viver, morrer e sentir. Porque atribuição alguma de significado é convencional, nenhuma é permanente para além do som que passa; todavia, a breve associação foi um lampejo de entendimento. O efeito duradouro é [...] tornar as coisas concebíveis mais do que armazenar proposições. Não é a comunicação, mas a introvisão (insight) que é dádiva da música; em uma frase muito ingênua, um conhecimento de "como vão as emoções" (p. 240241).

"A música é nosso mito da vida interior" (p. 242), conclui Langer, em uma afirmação que nos remete a O cru e o cozido, de Lévi-Strauss (2004), onde a análise do mito, a recorrer à diversidade das formas musicais, inspira-se no exemplo da música, que transita na "via intermediária entre o exercício do pensamento lógico e a percepção estética" (p. 33). 
A reflexão de Langer alcança e esclarece as questões da significação e simbolização, a desvelar os seus fundamentos, e revela o domínio da ação do compositor no âmbito da significação. Este "articula complexos sutis de sentimento [...] conhece as formas de emoção e sabe manejá-las, 'compô-las'".

A reflexão de Langer se situa por inteiro no campo da "matéria significada". Esta, sem dúvida, a razão para o posicionamento epistemológico de Monelle (1992), para quem é crucial a contribuição de Langer. Porém, a ordem introduzida na vida emocional pela música, como o concebe Langer, é, para Monelle, uma ordem transcendente. Tais noções, escreve Monelle (p. 9), "não são relacionadas nem à semiótica, nem capazes de uma discussão em termos semióticos. [...] Onde a estética idealista formula uma filosofia da música, a semiótica meramente tenta abarcar uma teoria da música." ${ }^{5}$

O compositor, entretanto, não pode prescindir das luzes lançadas pela reflexão acerca da "matéria significada", dos recursos que esta reflexão lhe põe nas mãos, e nem da intrínseca perspectiva semiótica, que trata dos "processos maneiras - de significação". O compositor sequer separa estes campos, imbricados no processo criativo.

\section{Análise semântica de Três Canções sobre Poemas de Fernando}

\section{Pessoa}

Guiados pelo paradigma da música como forma significativa ou simbólica, pelo anseio de tornar as coisas concebíveis, que orientou todo o processo criativo, empreenderemos a análise de Três Canções sobre Poemas de Fernando Pessoa com o intuito de revelar algumas soluções de "maneiras de significação" e seus vínculos com a "matéria significada". A análise não pretende ser e não é exaustiva, tarefa árdua mesmo para o compositor em razão da proliferação de fios e redes de significação no decorrer do próprio processo composicional, cuja reconstituição metódica não é possível.

Os três poemas, da poesia ortônima de Fernando Pessoa, não compõem um tríptico. Dorme enquanto eu velo ... e Dorme sobre o meu seio, primeira e terceira canções do ciclo, não possuem atribuição de data. Dorme, que a vida é

\footnotetext{
${ }^{5}$ Such notions are neither related to semiotics, nor capable of discussion in semiotic terms. [...] Where idealist aesthetics formulates a philosophy of music, semiotics merely tries to encompass a theory of music.
} 
nada!, segunda canção, é datado de 10 de outubro de 1933. São poemas autônomos que reunimos por reconhecer neles um conteúdo emocional comum, a mesma atmosfera onírica. A escolha dos poemas deu-se pela afinidade com o conteúdo, de um profundo niilismo idiossincrático e centrado no próprio indivíduo, e pelo desejo - necessidade estética e emocional - de empreender uma leitura musical dos poemas. A atitude composicional diante destes não é a de descrevê-los ou tentar transportar ou traduzir para o plano musical a sua complexa rede de significados tecida no universo do signo linguístico. Embora na música possamos nos apropriar dos elementos estruturais do poema, especialmente na manipulação da sua estrutura rítmica, sabemos, com Langer, na nossa prática musical, das impossibilidades quanto à constituição de funções denotativas, assim como das especificidades quanto à aplicação das funções conotativas. Musicar o poema representa o aporte da experiência, personalíssima num primeiro momento, da sua leitura. Passa por uma compreensão particular do quadro emocional - da sua lógica - a partir da qual se empreende a tarefa criativa da constituição da forma simbólica. Com esta e por seu intermédio, articular-se-á complexos sutis de sentimentos intrinsecamente vinculados aos poemas, mas cujas feições e caráter são próprios e específicos da interação entre poema e música. Nesta interação, a música assume o controle do desdobramento temporal e da entonação, com modulações significativas e novos relevos no campo semântico.

Deu-se a escolha dos poemas, também, pelo interesse no forte parentesco formal compartilhado pelos três poemas. Há um importante intercâmbio de elementos significantes e significados, que reverberam de um para os demais poemas, tornando-os nós de uma teia simbólica que, ao mesmo tempo em que os transcende, permite enxergá-los como um conjunto integrado. Esta visão é extremamente estimulante no que sugere de soluções musicais análogas. Todo o processo composicional é desde o início marcado por esta visão dos três poemas como um conjunto integrado, visão esta que é determinante nas decisões formais no âmbito puramente musical.

Em cada uma das Três Canções a música é que se expressa primeiro, a condensar em seções introdutórias o estado emocional que domina cada canção como um todo. $\mathrm{O}$ espectro emocional é definido pela música. $\mathrm{O}$ texto vem, em seguida, esclarecer e conferir precisão aos marcos expressivos fixados de início 
pela música. Marcos expressivos que dissolvem a linha divisória entre a realidade e o sonho, e entre o sonho e o "sonhando de sonhar".

Assim como encontramos nos poemas termos que são verdadeiros canais de comunicação portadores de significado entre os poemas, empenhamo-nos em construir termos musicais com funções equivalentes, capazes de replicar na dimensão musical uma função semiótica análoga, a desempenhar no plano musical funções similares de conexão e integração. Exemplifiquemos, em primeiro lugar, com a solução integradora da qual nos valemos para introduzir o termo "Dorme", primeiro signo de cada um dos três poemas, que fixa os limites da fronteira entre o real e o onírico. Como mostra o Ex. 1, é sempre o Sol\# 3 e a mesma célula rítmica que ao termo "Dorme" se funde, a estender e aprofundar os laços que ligam os três poemas no seu primeiro e mais fundamental apelo significativo ao leitor.

a.

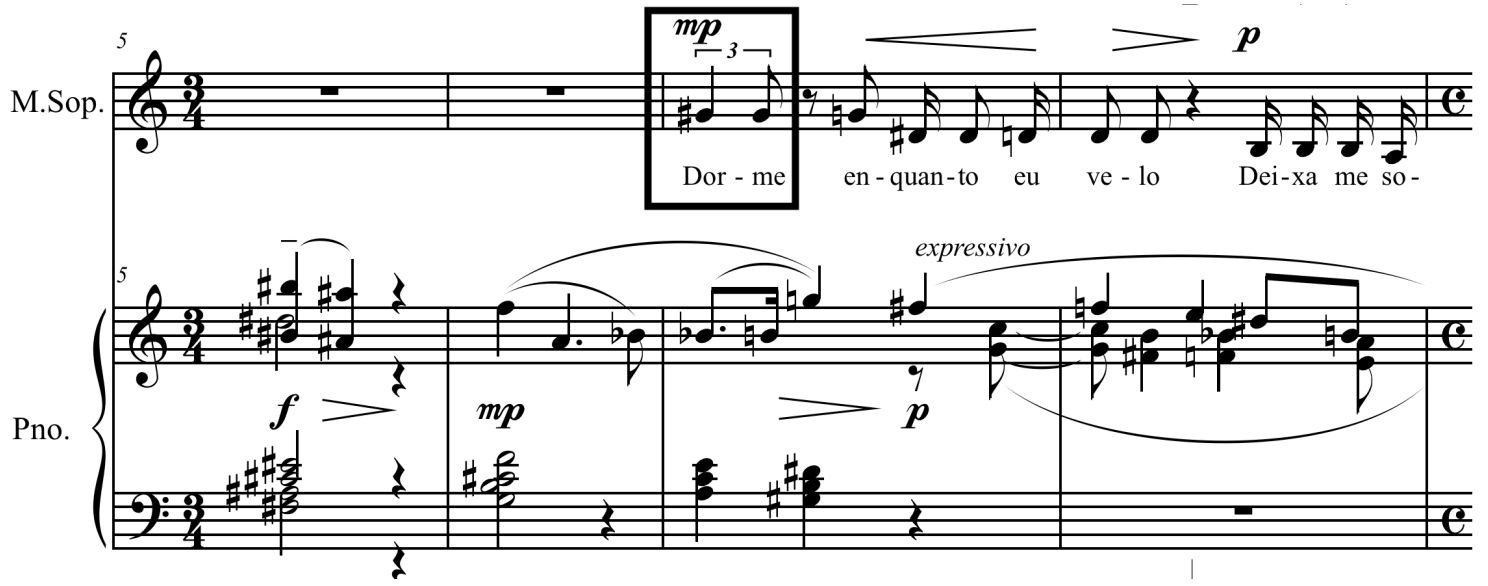

b.

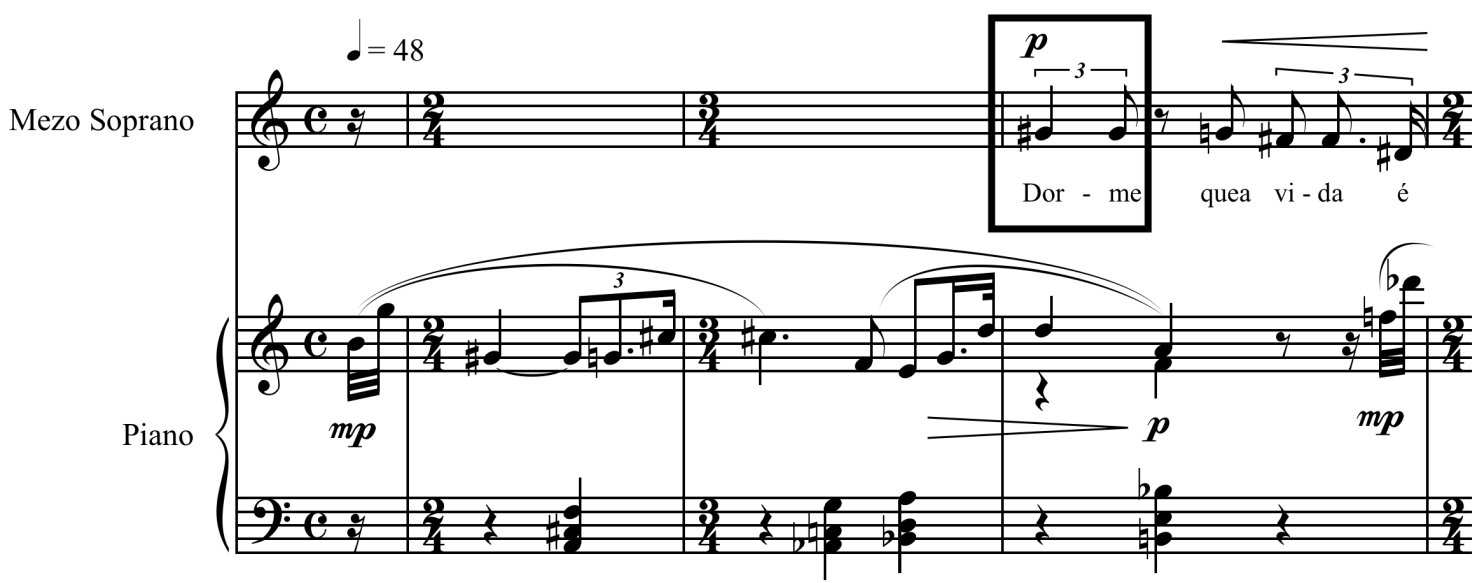


c.

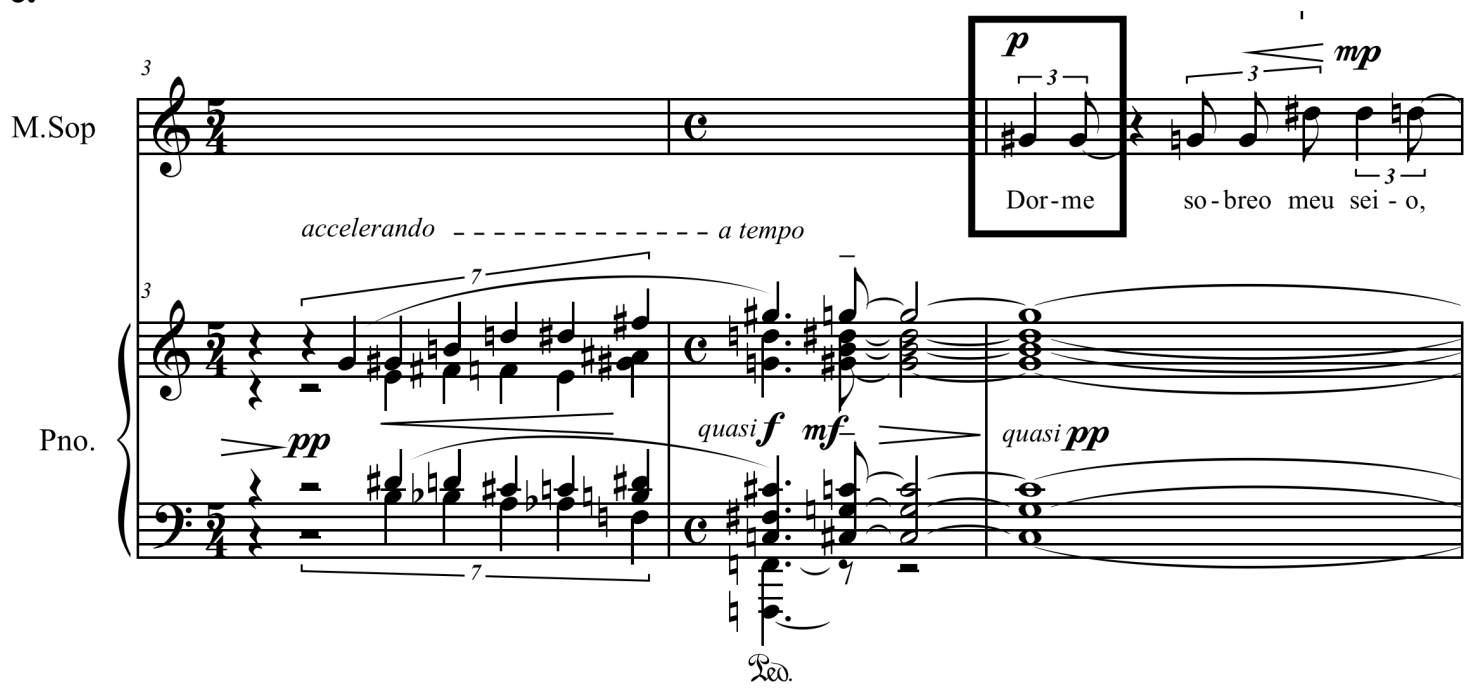

Exemplo 1: Figura musical integradora, em Sol $\# 3$, que se funde ao signo "Dorme", na primeira manifestação da voz em cada canção ( $a, b$ e c $)$, a estender e aprofundar os vínculos estruturais e simbólicos entre as três canções

A mesma função, conectora e integradora, é assumida pelo motivo apresentado no compasso 18 da primeira das Três Canções. A sua função expressiva é o desalento, em movimento convergente com o movimento melódico da voz no verso "Os meus desejos são cansaços". Na primeira das Três Canções, como está indicado no Ex. 2, este motivo tem função exclusivamente integradora, não é estruturante, e não retorna, sendo esta e, em seguida, sua reiteração variada suas únicas manifestações.

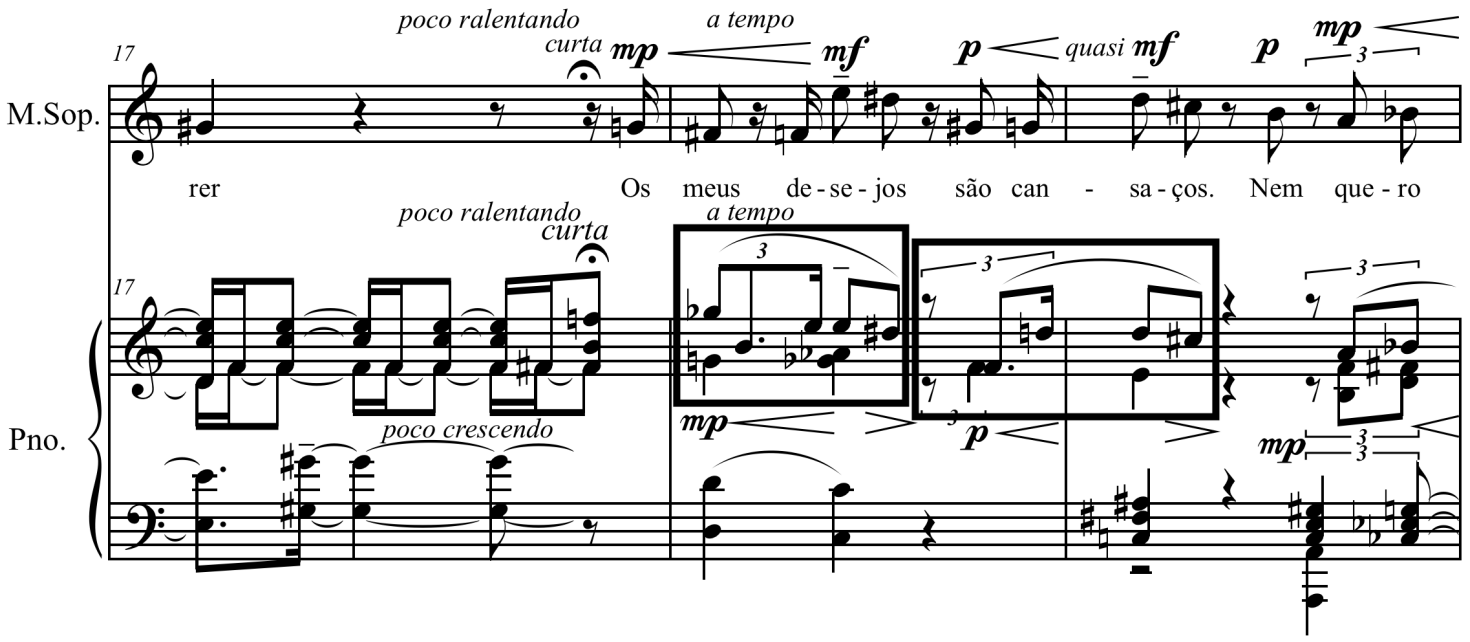

Exemplo 2: Ocorrência na primeira das Três Canções, na voz superior do piano, de motivo estruturante da segunda canção 
MUSICA THEORICA Revista da Associação Brasileira de Teoria e Análise Musical 2019, v. 4, n. 2, p. 134-158 - Journal of the Brazilian Society for Music

Na segunda das Três Canções, ao contrário, este mesmo motivo compõe o tema principal desta, exposto já na seção introdutória, o que se evidencia no Ex.3. Este tema principal, especialmente o movimento anacrústico que lhe é característico, é índice do niilismo enunciado nas expressões "a vida é nada" e "tudo é vão". O motivo antes apresentado nos compassos 18 e 19 da primeira canção acrescenta o desalento de "Os meus desejos são cansaços" ao niilismo enunciado nos dois primeiros versos da segunda canção.

Mezo Soprano

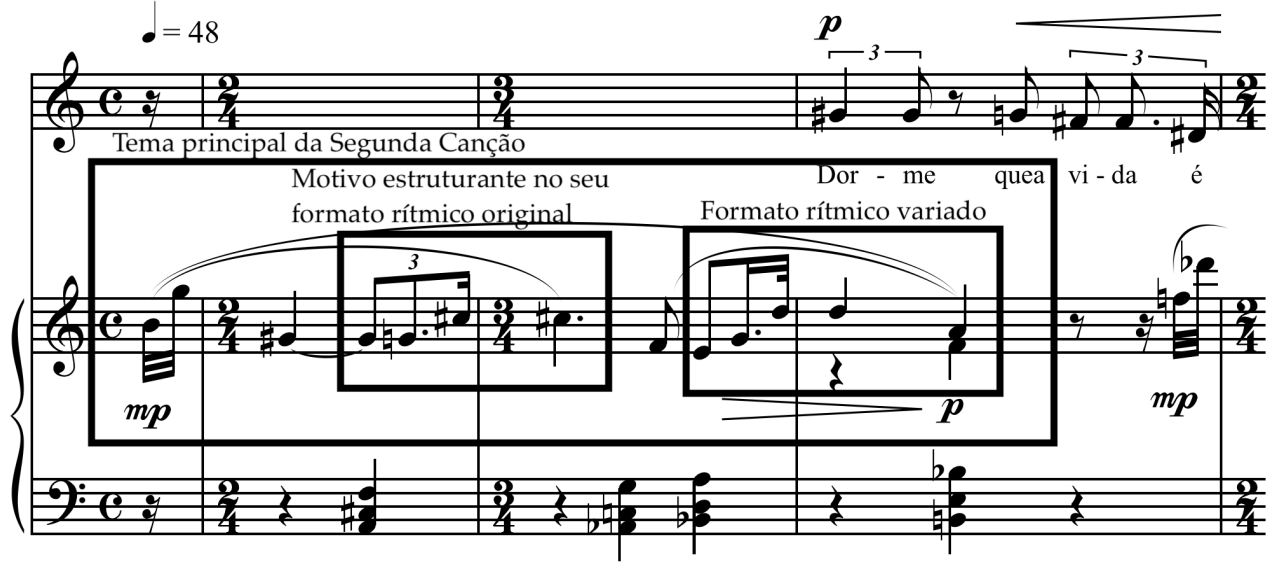

Exemplo 3: Integração do motivo estruturante, presente nas três canções, à composição do tema principal da segunda das Três Canções, apresentado pelo piano, no seu formato rítmico original e, em seguida, variado

Este mesmo motivo estruturante, determinante na composição do tema principal da segunda das Três Canções, tem papel fundamental na estruturação e organização de arcos melódicos de amplitudes diversas, como o demonstra o Ex. 4, onde o motivo estruturante está indicado pela letra A. 

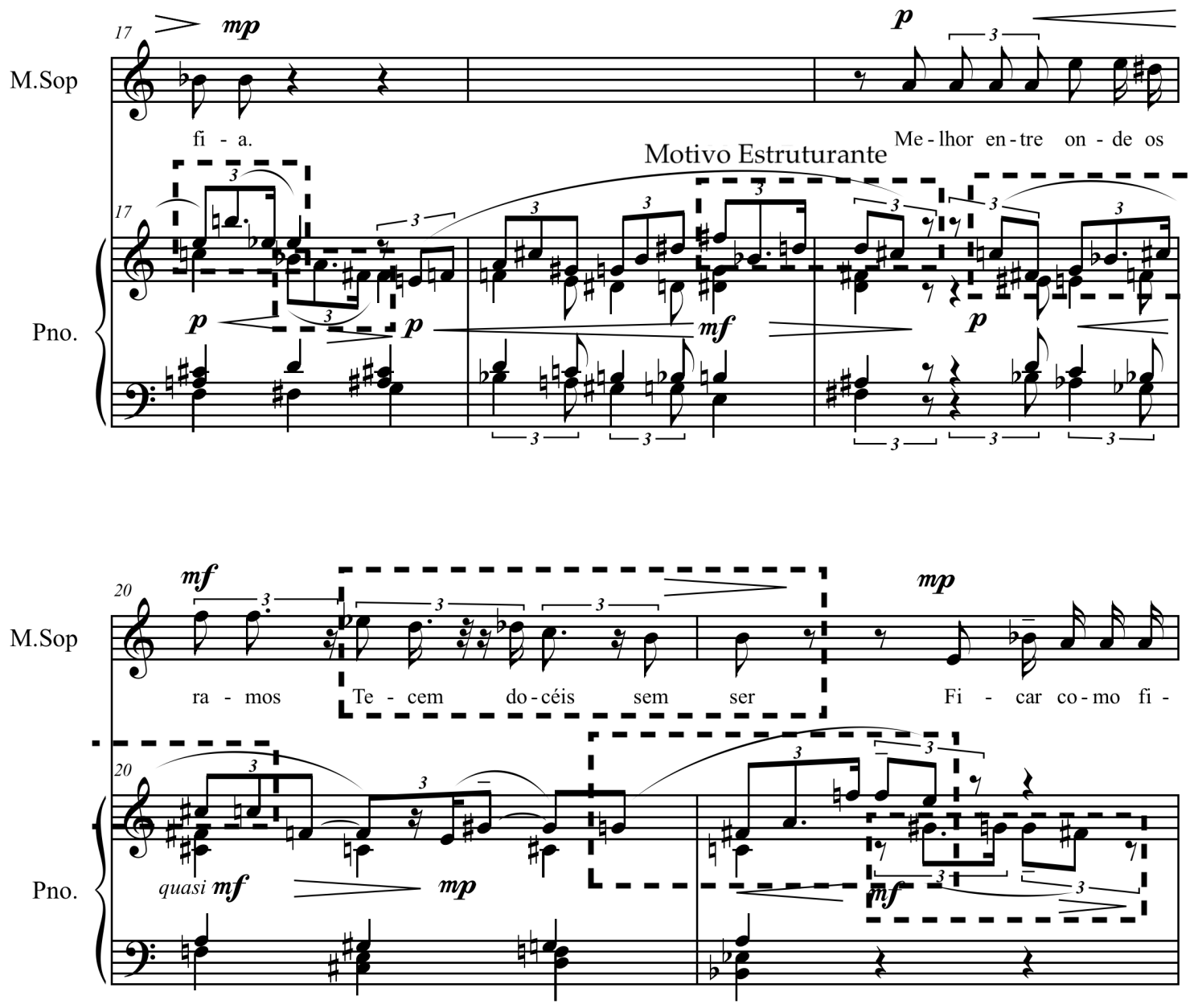

Exemplo 4: Excerto da segunda canção, composto a partir do motivo estruturante, que é fundamental na composição da segunda das Três Canções, assim como de todo o ciclo em razão de sua função integradora. A recorrência do motivo estruturante, a dar materialidade ao sentido poético de "Tecem docéis", está indicada em tracejado

É da composição do poema, além da organização rítmica, o recurso a "espaços vazios de texto", mas não desprovidos de sentido, tanto para a configuração formal assim como para a ênfase expressiva. Estes "espaços" são fixados e perceptíveis na imagem do poema, na disposição de seus versos e estrofes. Com estes "espaços", vibrados pelo pulso rítmico que anima o verso, articula-se a forma do poema. A música se apropria destes "espaços" para, somente ela, comentar ou ampliar o sentido do que já foi dito em texto e música, prenunciar, construir relações e vínculos significativos no interior da própria canção, a remeter ou fixar novos signos e símbolos, construir relações e vínculos significativos, simbólicos e estruturais entre as três canções. Tomemos o exemplo do compasso 12 da terceira canção, incluído o essencial movimento anacrústico. 
MUSICA THEORICA Revista da Associação Brasileira de Teoria e Análise Musical 2019, v. 4, n. 2, p. 134-158 - Journal of the Brazilian Society for Music

A frase melódica exposta pelo piano - tema secundário na terceira das Três Canções - a se apropriar do espaço que separa as duas primeiras estrofes do terceiro poema, com o movimento anacrústico que lhe é característico, é a reiteração integradora - sob a ação do processo de elaboração motívico-temática - do tema principal a partir do qual se erigiu a segunda canção, como indicamos no Ex. 5. Na segunda canção, reiteramos, este tema está intrinsecamente associado ao niilismo expresso em "a vida é nada" e em "tudo é vão". É índice, no sentido da teoria semiótica de Peirce, ${ }^{6}$ do conteúdo destas expressões. A aparição deste tema na terceira das Três Canções prenuncia o conteúdo do verso "tudo é nada", que é ao mesmo tempo eco e síntese das expressões "a vida é nada" e "tudo é vão", do segundo poema. O tema é concluído com o motivo característico da terceira canção, primeiro movimento melódico a abrir a introdução, índice de "sonhar" e "sonho", a sublinhar e dar profundidade - a acrescentar uma dimensão emotiva - a "tudo um sonho finge ser".

\footnotetext{
${ }^{6}$ Ver Monelle (1992), p. 198-199.
} 

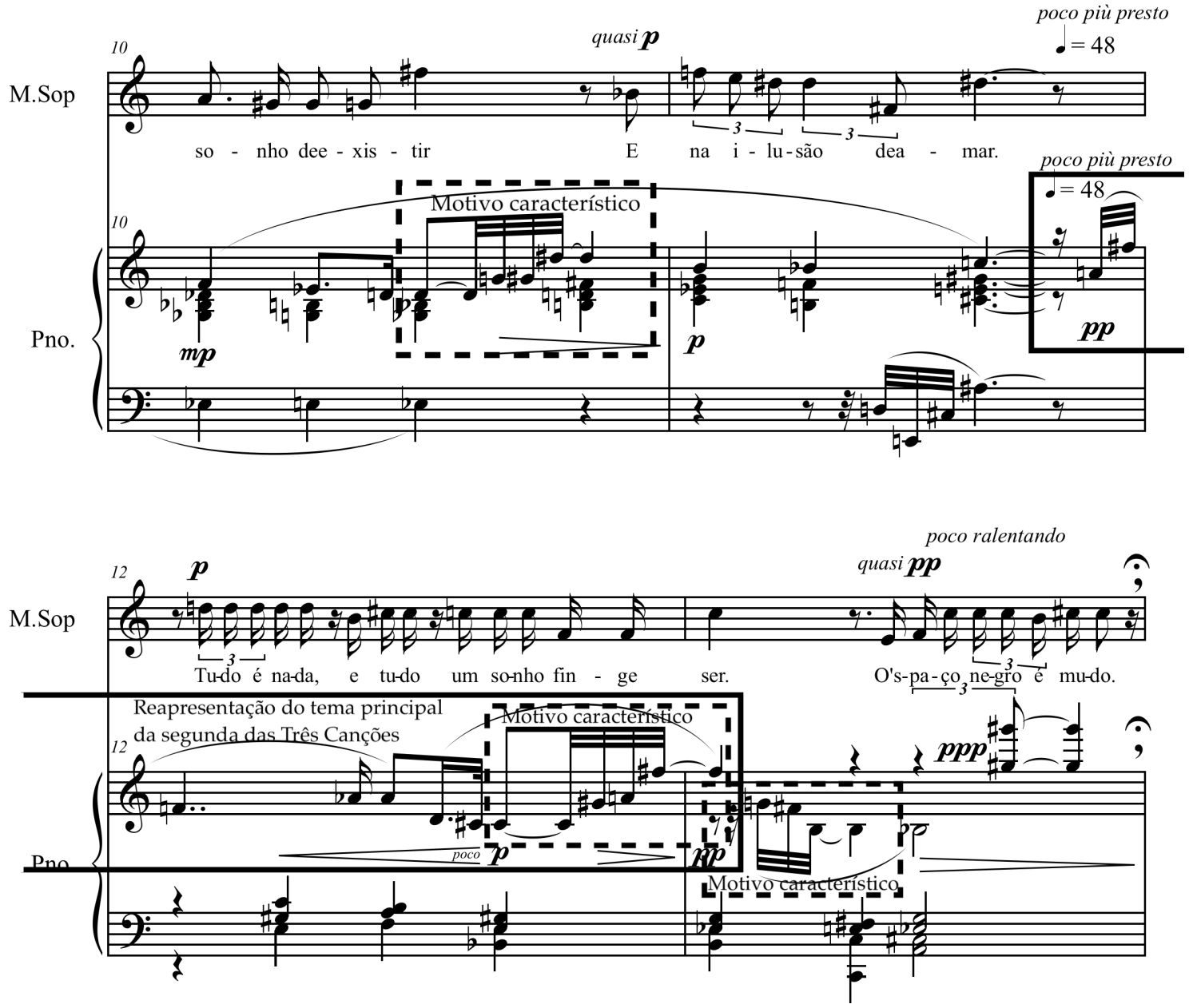

Exemplo 5: Reiteração integradora do tema principal da segunda canção na terceira das Três Canções, a prenunciar o verso - "Tudo é nada, e tudo" - do terceiro poema. A recorrência do motivo característico da terceira canção está indicada em tracejado

A mesma função expressiva tem a reapresentação variada do mesmo tema principal da segunda canção nos compassos 16 e 17 da terceira das Três Canções, como é mostrado no Ex. 6. Enquanto a voz canta "Dorme sobre o meu seio,/Sem mágoa nem amor...", a música, em contraponto, é índice de desalento, "a vida é nada", "tudo é vão" e "tudo é nada". O percurso dramático do tema - composto de motivos ocorrentes nas três canções, submetido à elaboração motívicotemática - é ele próprio desenvolvedor de uma teia de significados, que se agregam e modulam, no decorrer do percurso, em complexa interação com os três poemas. 


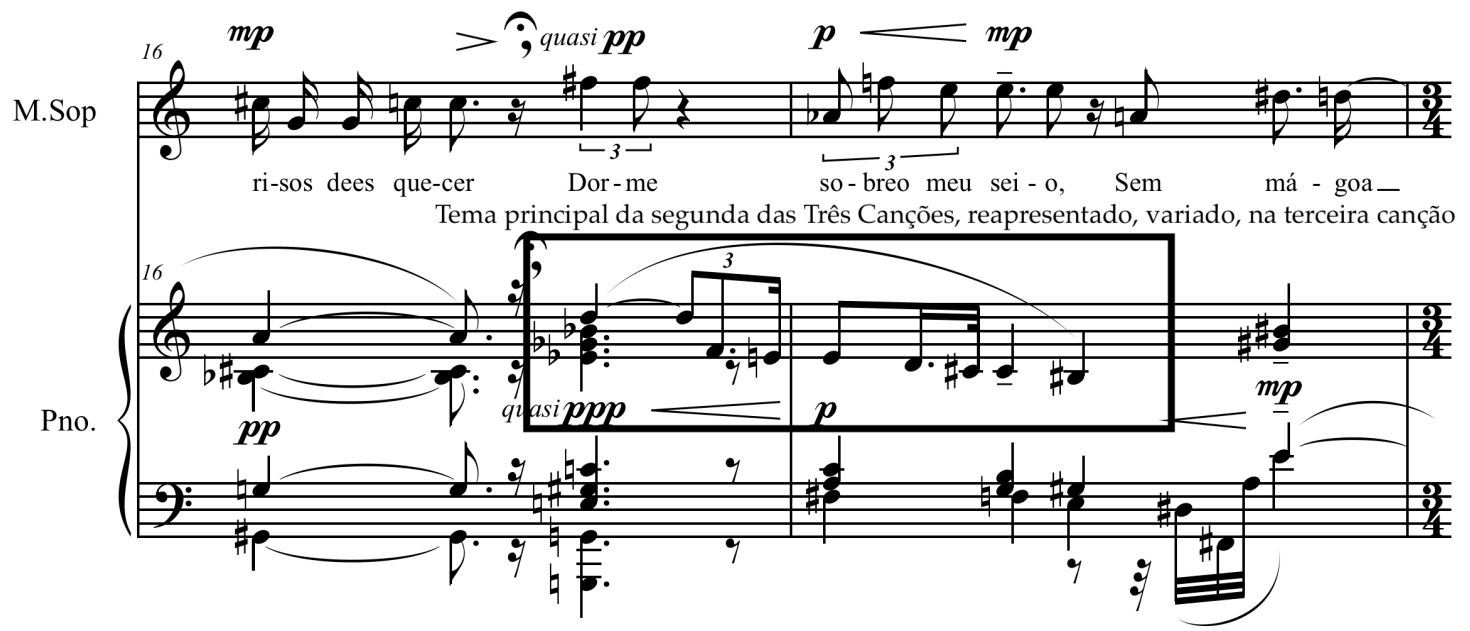

Exemplo 6: Última reapresentação, variada, integradora, do tema principal da segunda canção nos compassos 16 e 17 da terceira canção. Nesta última aparição, o tema traz consigo toda a carga simbólica acumulada em seu percurso dramático, constituindo-se em índice de desalento, "a vida é nada", "tudo é vão" e "tudo é nada"

O exercício primário da função integradora-concomitante com outras funções estruturais, melódicas e harmônicas-sob e sobreposto aos níveis de integração já vistos nos exemplos anteriores, esta função primária de integração é exercida pelo conjunto de alturas Sol\#-Sol-Ré\#-Réł. É interessante assinalar que a decisão de atribuir a este conjunto de alturas a função estrutural e integradora primordial de todo o ciclo foi tomada após a análise conjunta com o Prof. Dr. Celso Giannetti Loureiro Chaves, do Programa de Pós-Graduação da Universidade Federal do Rio Grande do Sul, dos então compostos quinze primeiros compassos de Dorme enquanto eu velo... A decisão resultou da sugestão de Chaves em reflexão, sobretudo, acerca da intenção do autor em desenvolver o que Chaves denominou de novo madrigalismo, e, também, do perceptível potencial estruturante do conjunto de alturas, identificado por Chaves, já prenunciado na fusão deste com o primeiro verso do poema, assim como da sua derivação em outras figuras. Obviamente, a adoção deste conjunto de alturas, Sol\#-Sol-Ré\#-Ré, em funções primordiais impôs a revisão do trecho já composto, para a consolidação desde o início das funções então atribuídas. Impôs, também, profunda mudança na orientação das ações composicionais.

O conjunto de alturas, Sol\#-Sol-Ré\#-Ré, tanto é o fundamento e ferramenta para a composição dos tecidos estruturais nas suas diversas camadas, quanto se manifesta, explicitamente, na superfície da textura musical na forma de figuras melódicas e harmônicas. Está na base da construção melódica e 
harmônica das Três Canções, é o núcleo motívico do argumento musical, principal fundamento e determinante da composição e elaboração temática, possui caráter seminal, e, ao mesmo tempo, é a mais poderosa força integradora a ligar entre si as canções e suas redes de significação em um grande quadro simbólico. É-lhe assignado força poderosa o suficiente para manter orbitando em torno dos conteúdos poético e musical a diversidade dos elementos postos em jogo. Expomos a função estrutural primordial do conjunto de alturas Sol \#-Sol-Ré»-Ré, ilustrando-a com os Exs. 7, 8 e 9, extraídos, respectivamente, da primeira, segunda e terceira das Três Canções.

a.

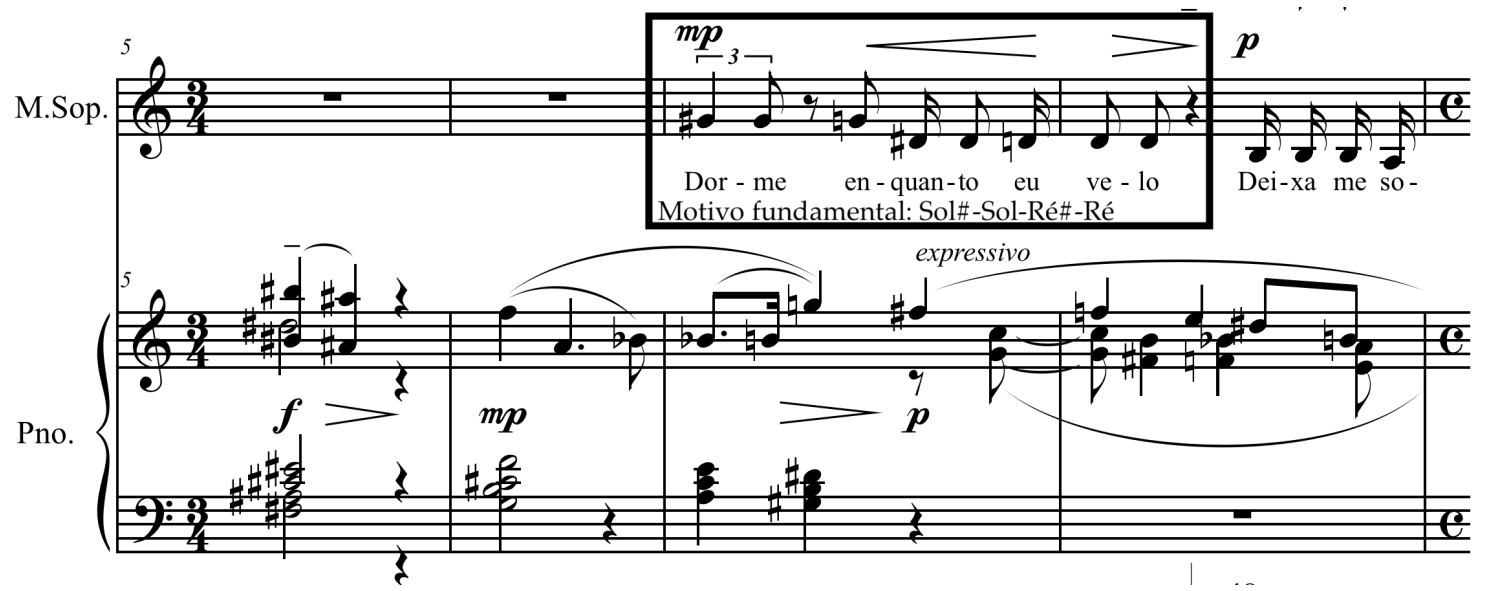


MUSICA THEORICA Revista da Associação Brasileira de Teoria e Análise Musical 2019, v. 4, n. 2, p. 134-158 - Journal of the Brazilian Society for Music

b.
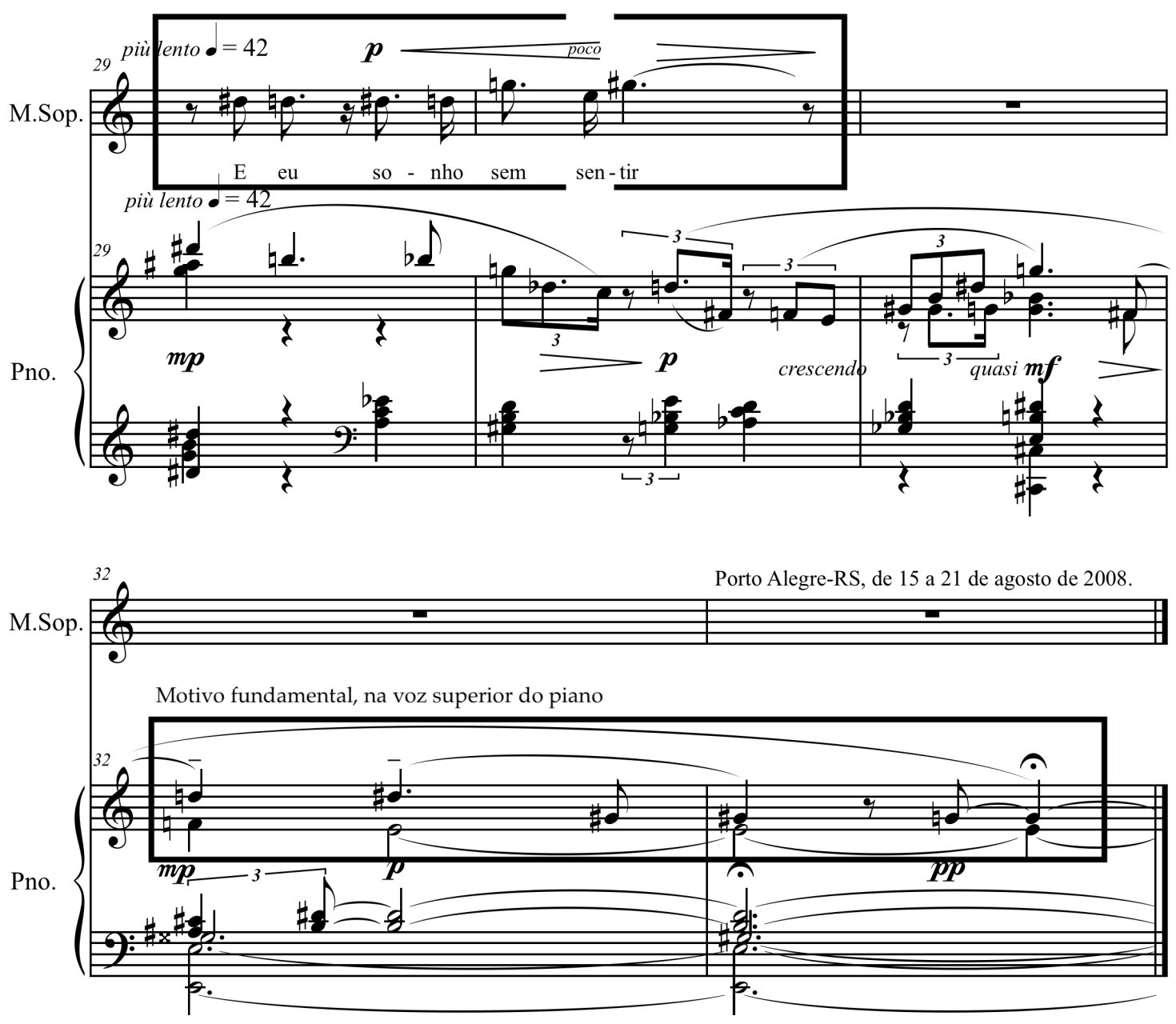

Exemplo 7: Identificação na primeira das Três Canções da ocorrência melódica do conjunto de alturas ou motivo fundamental Sol $\sharp S o l-R e ́ \# R e ́$. 
a.

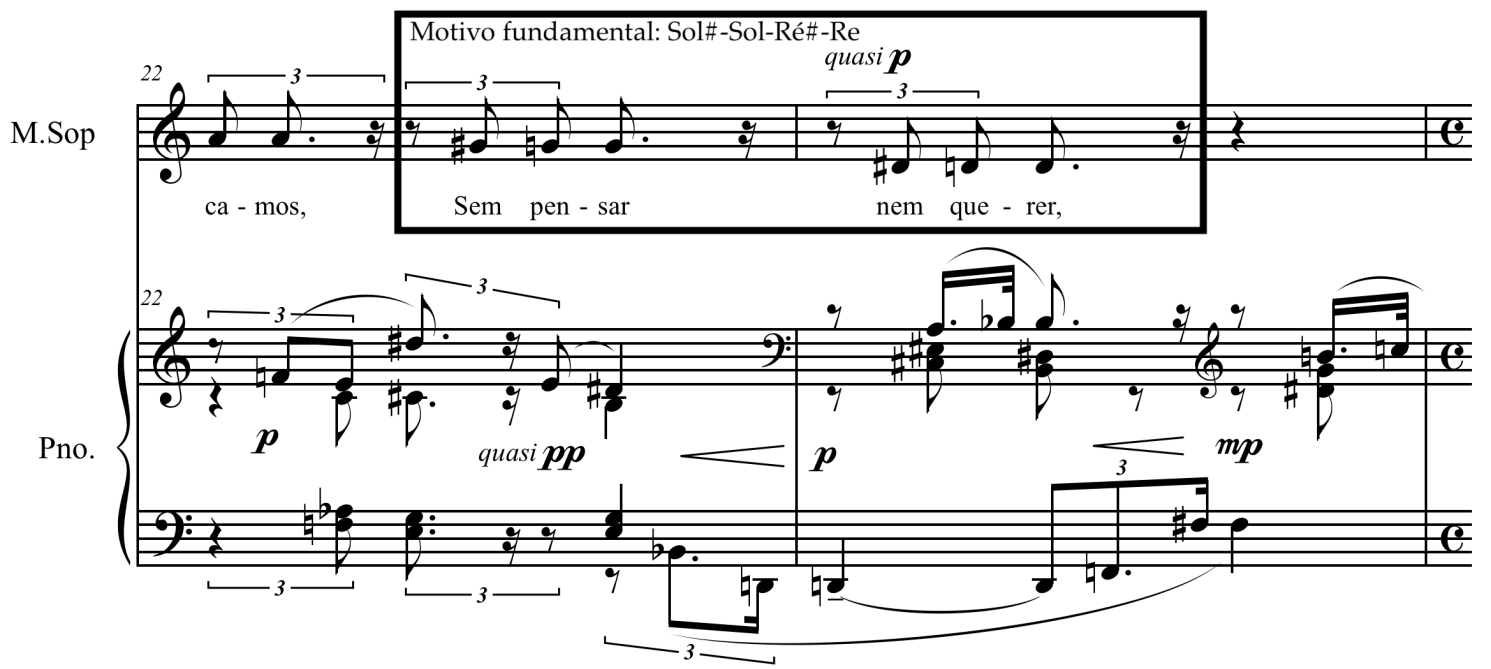

b.
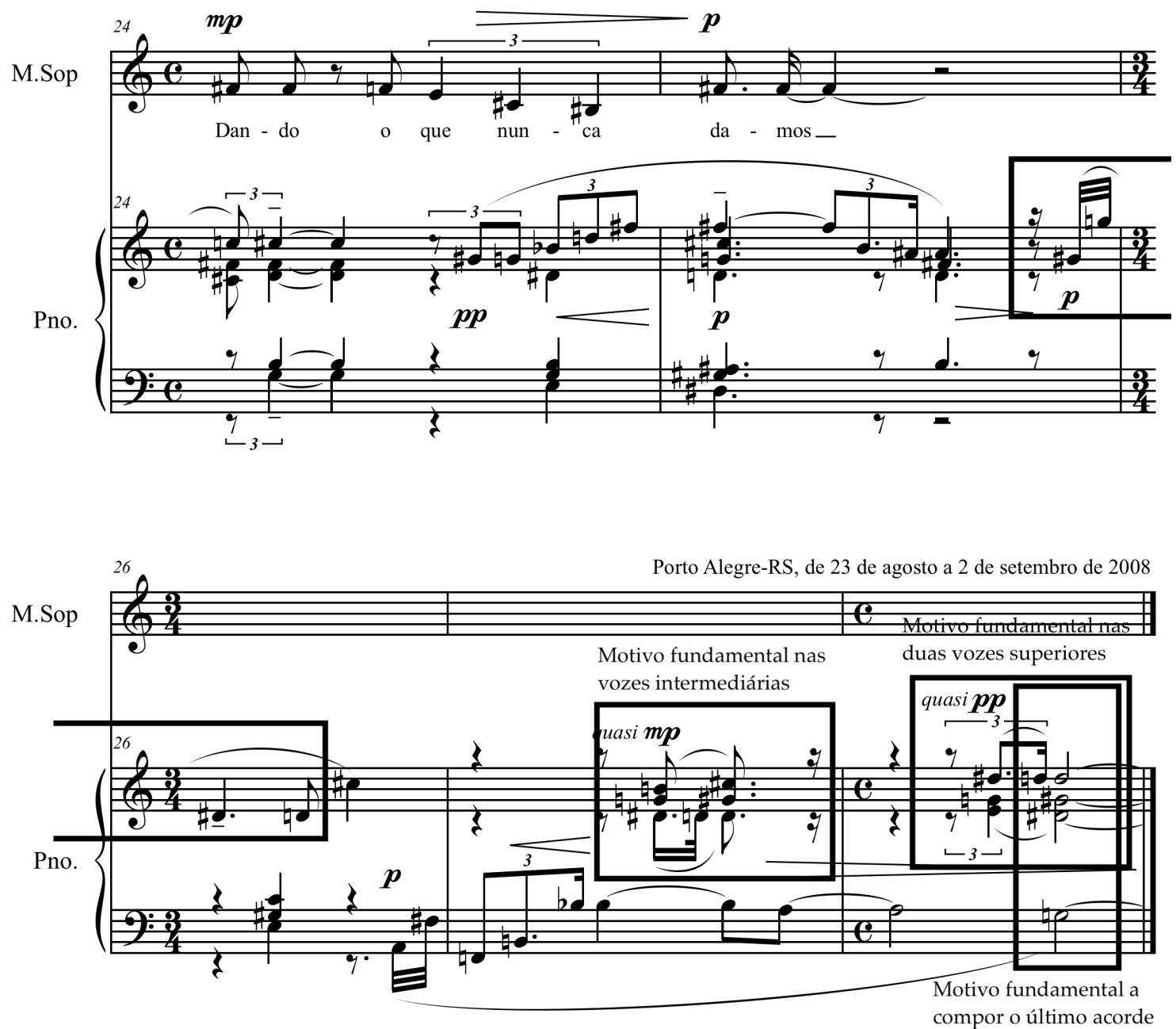

Exemplo 8: Identificação na segunda das Três Canções da ocorrência do conjunto de alturas ou motivo fundamental $\mathrm{Sol} \sharp S o l-R e ́ \# R e ́$ 
MUSICA THEORICA Revista da Associação Brasileira de Teoria e Análise Musical 2019, v. 4, n. 2, p. 134-158 - Journal of the Brazilian Society for Music

a.
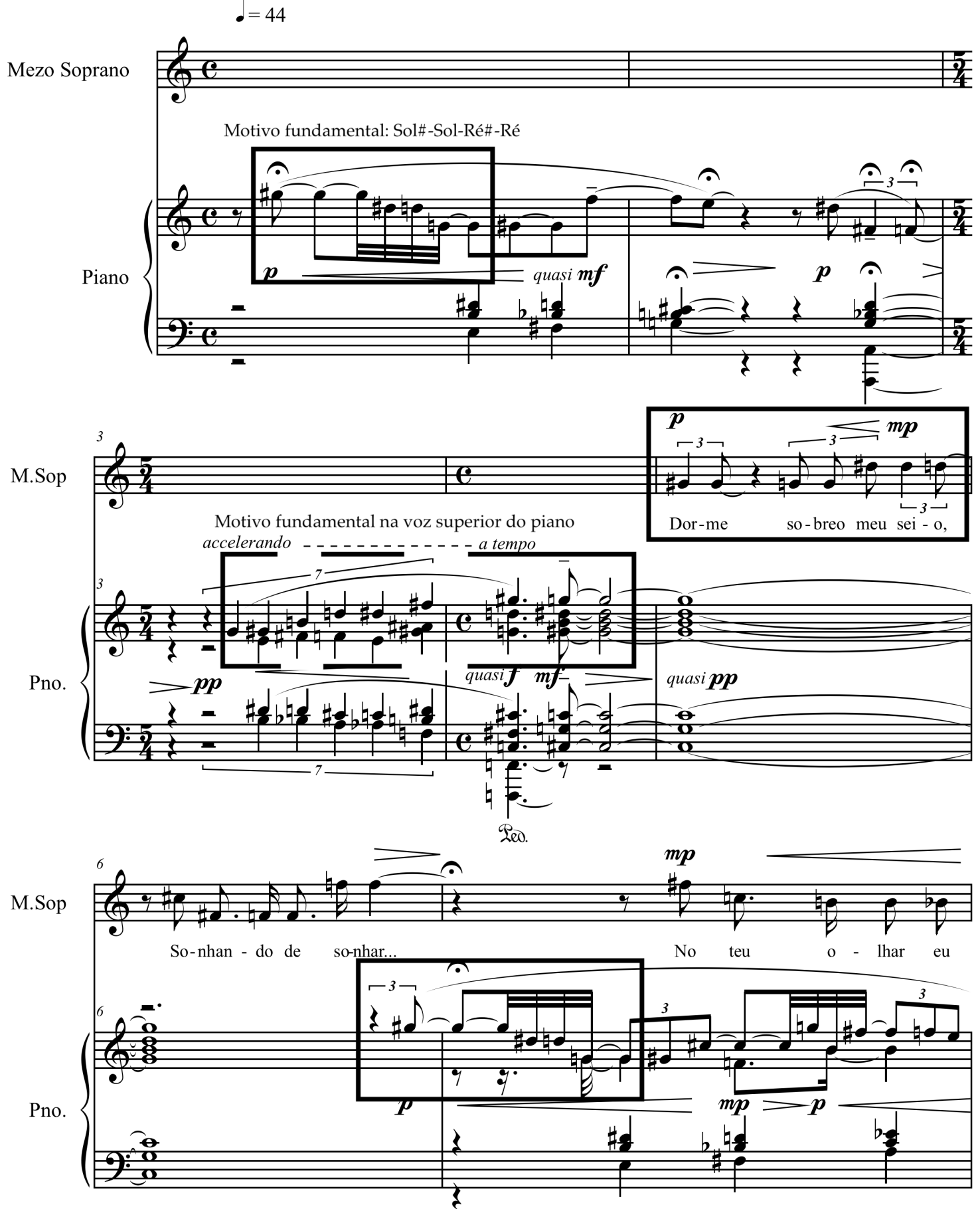
b.
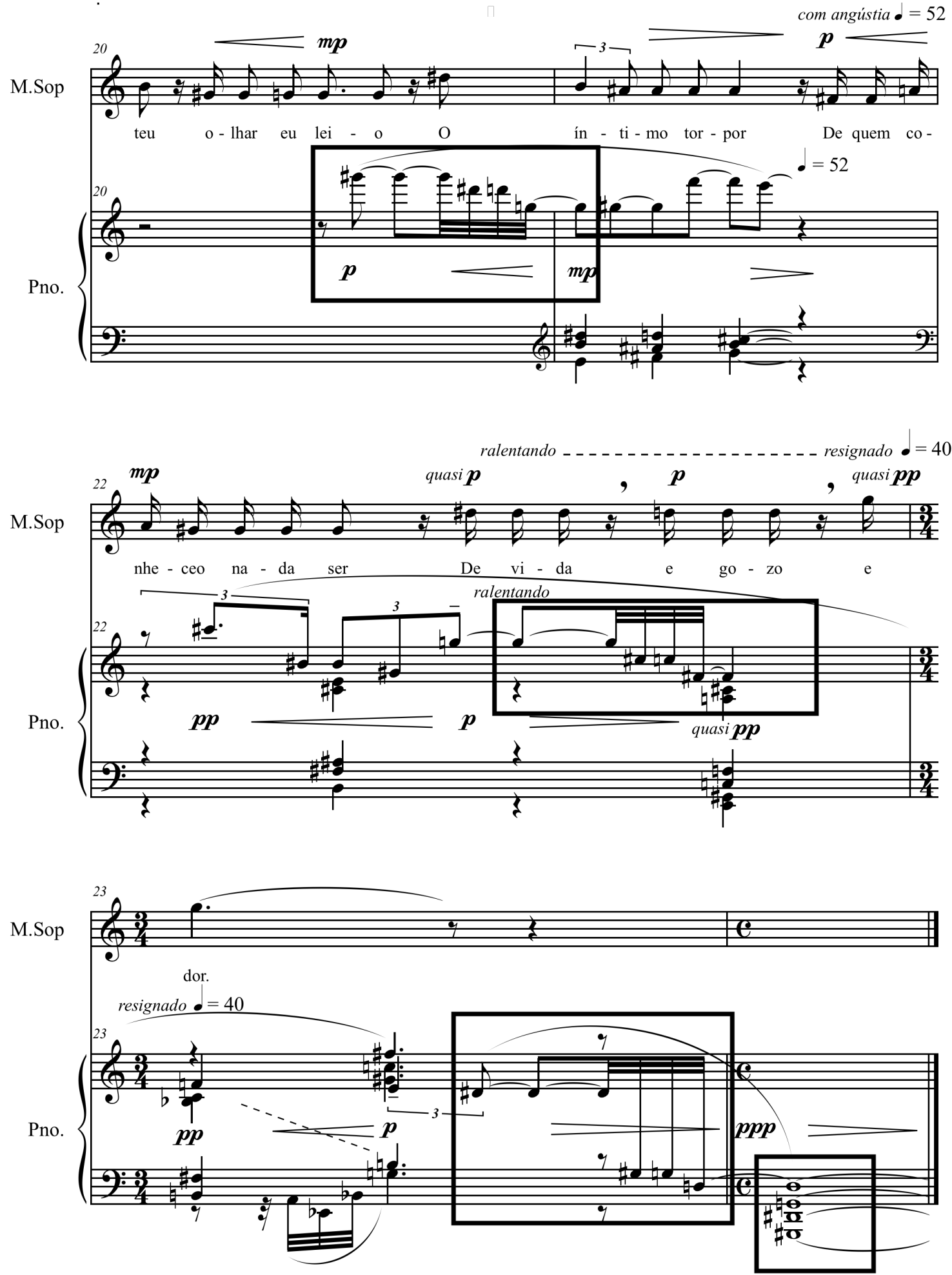

Exemplo 9: Identificação na terceira das Três Canções da ocorrência melódica e harmônica do conjunto de alturas ou motivo fundamental Sol -Sol-Ré $\#$ Ré, na sua forma original e com variação 
MUSICA THEORICA Revista da Associação Brasileira de Teoria e Análise Musical 2019, v. 4, n. 2, p. 134-158 - Journal of the Brazilian Society for Music

O motivo fundamental, nas suas várias manifestações, é símbolo do estado emotivo que domina os três poemas, marcado pela fuga da realidade para o sonho e deste para o sonho do sonho, numa espiral onde se reencontra, sempre, a negação niilista.

Ilustramos com um último exemplo a natureza diversa da interação entre texto e música. Esta pode enfatizar o conteúdo do texto, acrescentar-lhe outro conteúdo, divergir. Pode, também, contradizê-lo de modo complementar, como o ilustra o Ex. 10. Quando em Dorme enquanto eu velo ... o texto diz "A tua carne calma/É fria em meu querer.", a música - compassos 15 a 17 - se agita, em oposição à "carne calma", cuja expressão encontra-se no pedal em Dó4-Mi4. Absolutamente, a música não é "fria". A música ultrapassa a superfície do texto, a mergulhar nas suas profundezas a perscrutar-lhe os símbolos, a expandir os seus sentidos e a revelar e acrescentar novas significações possíveis, porém não informadas explicitamente pelo texto, mas propostas e legitimadas pela interação mesma entre texto e música. Esta, a música, aqui, não sublinha antes questiona a indiferença em relação ao desejo carnal, expressa pelo texto. 

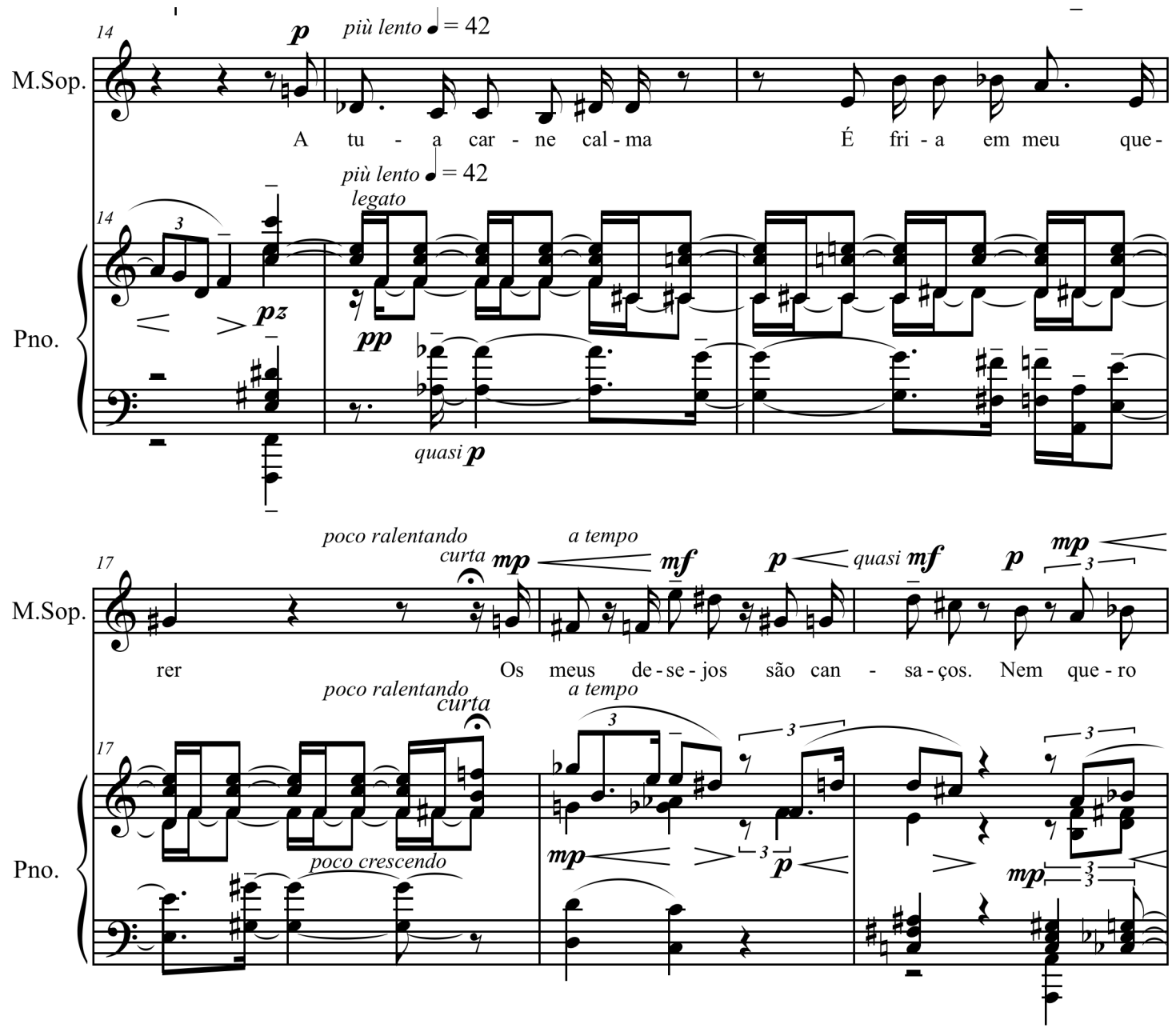

Exemplo 10: Interação complementar entre texto e música, onde esta questiona o conteúdo emocional do texto em "A tua carne calma/É fria em meu querer"

\section{Considerações finais}

Em Três Canções sobre Poemas de Fernando Pessoa exploramos, sobretudo, as potencialidades do signo musical na sua condição de índice. Segundo Peirce (2011) o índice "é um signo que se refere ao Objeto que denota em razão de ser realmente afetado por aquele Objeto"7 (p. 102); está "em conexão dinâmica (inclusive espacial) tanto, por um lado, com o objeto individual, quanto, por outro lado, com os sentidos ou memória da pessoa para quem serve como signo" 8

\footnotetext{
${ }^{7}[\ldots]$ is a sign which refers to the Object that it denotes by virtue of being really affected by that Object.

${ }^{8}[\ldots]$ in dynamical (including spatial) connection both with the individual object, on the one hand, and with the senses or memory of the person for whom it serves as a sign, on the other hand.
} 
MUSICA THEORICA Revista da Associação Brasileira de Teoria e Análise Musical 2019, v. 4, n. 2, p. 134-158 - Journal of the Brazilian Society for Music

(p. 107). Segundo Monelle (1992), em conformidade com Peirce, o "índice depende da associação por contiguidade, não associação por similaridade ou operações intelectuais"' $^{\prime \prime}$ (p. 198). Monelle (1992, p. 198) exemplifica:

Um buraco de bala em um painel de vidro é um índice, a significar um tiro ocorrido anteriormente. $\mathrm{O}$ modo de andar de um homem, que Peirce vê na rua, indica que ele é provavelmente um marinheiro. Uma batida na porta, $\mathrm{o}$ nível baixo do barômetro, um cata-ventos, o nível de bolha de ar, todos estes fenômenos são índices. Um grito espontâneo é também um índice, desde que proveniente de alguma causa. ${ }^{10}$

Em Três Canções sobre Poemas de Fernando Pessoa as relações de contiguidade entre texto e música e, em reverso, entre música e texto foram construídas e validadas no decorrer do próprio processo composicional. É convenção que se estabelece e somente tem legitimidade e vigência no interior do próprio ciclo de canções. Mas aí, nos limites do ciclo de canções, acreditamos, é plena de significação e de elevado valor simbólico.

\section{Referências}

1. Langer, Susanne K. 2004. Filosofia em nova chave. Tradução de Janete Meiches e J. Guinsburg. São Paulo: Editora Perspectiva.

2. Lévi-Strauss, Claude. 2004. O cru e o cozido. Tradução de Beatriz PerroneMoisés. São Paulo: Cosac \& Naify.

3. Monelle, Raymond. 1992. Linguistics and Semiotics in Music. London: Routledge.

4. Peirce, Charles Sanders. 2011. The Philosophy of Peirce: Selected Writings. Edited by Justus Buchler. New York: Dover Publications.

5. Rink, John. 2002. Analysis and (or?) performance. In: Musical Performance: a Guide to Understanding. Cambridge University Press, Cambridge.

\footnotetext{
${ }^{9}$ The index depends on 'association by contiguity, not association by resemblance or intellectual operations'.

${ }^{10} \mathrm{~A}$ bullet-hole in a glass pane is an index, signifying a past shot. The rolling gait of a man Peirce sees in the street indicates that he is probably a sailor. A rap on the door, a low barometer, a weathercock, a spirit-level, all these things are indices. A spontaneous cry is also an index, provided it arises from some cause.
} 


\section{Anexo - Poemas de Fernando Pessoa}

\section{Dorme enquanto eu velo...}

Dorme enquanto eu velo...

Deixa-me sonhar...

Nada em mim é risonho.

Quero-te para sonho,

Não para te amar.

A tua carne calma

É fria em meu querer.

Os meus desejos são cansaços.

Nem quero ter nos braços

Meu sonho do teu ser.

Dorme, dorme, dorme,

Vaga em teu sorrir...

Sonho-te tão atento

Que o sonho é encantamento

E eu sonho sem sentir.
Dorme, que a vida é nada!

Dorme, que a vida é nada!

Dorme, que tudo é vão!

Se alguém achou a estrada,

Achou-a em confusão,

Com a alma enganada.

Não há lugar nem dia

Para quem quer achar,

Nem paz nem alegria

Para quem, por amar,

Em quem ama confia.

Melhor entre onde os ramos

Tecem docéis sem ser

Ficar como ficamos,

Sem pensar nem querer,

Dando o que nunca damos.

\section{Dorme sobre o meu seio}

Dorme sobre o meu seio, Sonhando de sonhar...

No teu olhar eu leio

Um lúbrico vagar.

Dorme no sonho de existir

E na ilusão de amar.

Tudo é nada, e tudo

Um sonho finge ser.

$\mathrm{O}$ 'spaço negro é mudo.

Dorme, e, ao adormecer,

Saibas do coração sorrir

Sorrisos de esquecer.

Dorme sobre o meu seio,

Sem mágoa nem amor...

No teu olhar eu leio

O íntimo torpor

De quem conhece o nada-ser

De vida e gozo e dor. 